\title{
KAMPANYE PENTINGNYA HIMBAUAN MENCUCI TANGAN MELALUI MEDIA PAMFLET DI MASA PANDEMI COVID-19
}

\author{
M. Fahrudin Andriyansyah*, Dea Amy R, Valeriel Margarettha, Melia Indah M. \\ Fakultas Hukum, Universitas Islam Malang \\ *Korespondensi email: fahrudin@unisma.ac.id
}

\begin{abstract}
ABSTRAK
Awal tahun 2020 umat manusia di seluruh dunia digoncang dengan pandemi Virus Corona (Covid-19) yang membuat kepanikan dimana-mana. Ratusan ribu manusia terinfeksi dan ribuan lainnya meninggal dunia. Sedangkan di Indonesia pemerintah telah mengeluarkan sejumlah kebijakan penanggulangan dan penanganan pandemi covid-19, salah satunya adalah dengan menerapkan protokol kesehatan bagi masyarakat. Akan tetapi dalam pelaksanannya masih banyak masyarakat yang tidak mengindahkan himbauan ini. berangkat dari kondisi tersebut, Kuliah Kerja Nyata (KKN) Tematik Kelompok 2 UNISMA melakukan pengabdian kepada masyarakat pada saat masa pandemi covid-19. KKN Kelompok 02 melakukan kegiatan pengabdiian dengan memberikan informasi kepada warga untuk mematuhi protokol kesehatan dengan memberikan fasilitas tempat cuci tangan dan penempelan pamflet berisi anjuran protokol kesehatan. Media yang dipergunakan untuk mengajak warga atau kampanye yaitu melalu media pamflet. Hasil pelaksanaan pengabdian telah merubah perilaku masyarakat yang sebelumnya abai terhadap protocol kesehatan menjadi lebih peduli terhadap penerapan protocol kesehatan demi mencegah dan menanggulangi pandemi covid-19.
\end{abstract}

Kata Kunci: kampanye, protocol, kesehatan, covid-19, masyarakat.

\section{PENDAHULUAN}

Corona virus desaster 2019 atau covid-19 telah menjadi pandemi hampir di seluruh negara dunia. Virus ini berawal dari Cina lebih tepatnya di Kota Wuhan dan menyebar dengan sangat cepat ke berbagai Negara (Supriatna, 2020). Saat ini Amerika Serikat (AS) tercatat sebagai Negara yang memiliki kasus covid-19 terbanyak di dunia, dengan tambahan 29.923 pasien positif. Dengan begitu, akumulasi kasus keseluruhan yang terkonfirmasi di AS menjadi 6.706.524 jiwa, dengan 3.968.885 di antaranya sudah kembali pulih. Di Indonesia sendiri penyebaran covid-19 ini sangat cepat dan menyebar di seluruh provinsi (Mona, 2020; Yunus \& Rezki, 2020).

Kondisi tersebut sangat penting mendapatkan perhatian pemerintah, karena penyebaran virus Covid-19 beberapa bulan belakangan ini telah menimbulkan keresahan bagi semua kalangan masyarakat (Maria \& Raharjo, 2020; Elgaputra et al., 2020). Namun, seiring berjalannya waktu banyak sekali isu-isu yang tidak bertanggung jawab berkembang dengan pesatnya dan menjadi masalah penting dalam pencegahan dan pengendalian wabah Covid-19. Minimnya pengetahuan masyarakat mengenai virus Covid-19 ini menimbulkan dampak sosial yang besar (Yamali \& Putri, 2020).

Jumlah kasus covid-19 yang terus bertambah setiap harinya membuat organisasi kesehatan dunia atau WHO mengeluarkan kebijakan agar semua negara menerapkan sosial distancing atau physical distancing termasuk menerapakan pola hidup sehat, seperti makan 
makanan bergizi, olahraga, selalu memakai masker, jaga jarak, cuci tangan setiap saat dan lain sebagainya (Janitra, Wijayanti, Wahyuningsih, \& Apriyanti, 2020). Hal ini dilakukan untuk pencegahan covid-19, namun faktanya di dalam masyarakat masih ada saja yang acuh terhadap permasalahan ini, mereka menganggap sepele akan bahaya covid-19 (Yatimah, Kustandi, Maulidina, Irnawan, \& Andinnari, 2020). Kondisi ini juga terjadi di desa desa Kalijambon, Kecamatan Tembelang, Kabupaten Jombang. Masyarakat kurang memahami tentang urgensi penerapan protocol kesehatan terutama tidak mengertinya masyarakat tentang bahaya tidak mencuci tangan setiap selesai beraktifitas. Dampak yang disebabkan sangat besar, karena tangan setiap saat menyentuh berbagai macam barang yang tertempel kuman, bakteri atau bahkan virus (covid-19).

Agar masyarakat memahami pentingnya mencuci tangan maka diperlukan media kampanye yang efektif. Salah satunya adalah melalui media pamflet. Kampanye merupakan adalah sebuah tindakan dan usaha yang bertujuan mendapatkan pencapaian dukungan, usaha kampanye bisa dilakukan oleh peorangan atau sekelompok orang yang terorganisir untuk melakukan pencapaian suatu proses pengambilan keputusan di dalam suatu kelompok. Kampanye biasa juga dilakukan guna memengaruhi, penghambatan, pembelokan pecapaian. Kampanye umumnya dilakukan dengan slogan, pembicaraan, barang cetakan, penyiaran barang rekaman berbentuk gambar atau suara, dan simbolsimbol (wikipedia).

Berangkat dari kondisi tersebut Kelompok 02 Kuliah Kerja Nyata (KKN) Tematik Universitas Islam Malang (UNISMA) melakukan program pengabdian kepada masyarakat agar bisa berkontribusi memberikan pemahaman kepada masyarakat tentang pentingnya menerapakan protocol kesehatan di tengan pandemi covid-19 melalui kampanye menggunakan media pamflet. Termasuk mengajak masyarakat untuk rajin mencuci tangan dengan menyediakan fasilitas cuci tangan. Program pengabdian ditujukan

\section{METODE}

Kegiatan KKN Tematik edisi New Normal kelompok 02 UNISMA dilaksanakan pada tanggal 3 Agustus sampai dengan 3 September 2020. Tempat pelaksanaan kegiatan ini di desa Kalijambon, Kecamatan Tembelang, Kabupaten Jombang dan didekat masjid desa. Strategi pencapaian program kerja ini dilakukan melalui tiga tahapan. Tahapan pertama adalah perencanaan, yang dimulai dengan perizinan dan menganalisis situasi di lapangan. Pada tahapan ini, semua informasi mengenai sasaran dan program yang akan dijalankan sudah ditelusuri, termasuk juga pembuatan pamflet. Tahapan kedua adalah tahap pelaksanaan kampanye mencuci tangan di masa pandemi covid-19. Tahap selanjutnya yaitu monitoring dan evaluasi.
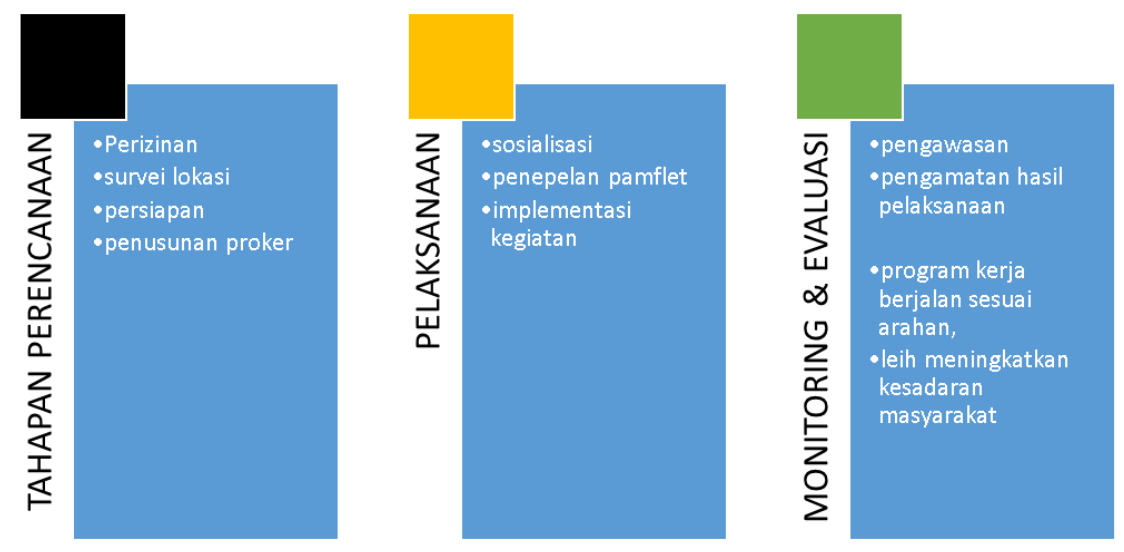

Gambar 1. Tahapan Pelaksanaan Pengabdian 


\section{HASIL DAN PEMBAHASAN}

\section{Perencanaan}

Perencanaan adalah suatu proses menentukan hal-hal yang ingin dicapai (tujuan) di masa depan serta menentukan berbagai tahapan yang diperlukan untuk mencapai tujuan tersebut. perencanaan (planning) dapat juga didefinisikan sebagai suatu kegiatan yang terkoordinasi untuk mencapai tujuan tertentu dalam kurun waktu tertentu. Dengan begitu, di dalam perencanaan akan terdapat aktivitas pengujian beberapa arah pencapaian, mengkaji ketidakpastian, mengukur kapasitas, menentukan arah pencapaian, serta menentukan langkah untuk mencapainya. Tahapan pertama adalah Perencanaan, yang dimulai dengan perizinan dan menganalisis situasi di lapangan. Pada tahapan ini, semua informasi mengenai sasaran dan program yang akan dijalankan sudah ditelusuri, termasuk juga pembuatan pamflet serta penyusunan program kerja yang dilakukan pada awal minggu pertama.

\section{Pelaksanaan}

Pelaksanaan merupakan sebuah tindakan dan implementasi dari program yang telah disusun bersama, di mana hal ini dilaksanakan sesuai dengan rencana yang disusun dan dipantau oleh pembimbing lapangan kegiatan KKN. Tahapan pelaksanaan merupakan implementasi program kerja dalam bentuk kampanye melalui penyebaran pamflet dan menyediakan fasilitas cuci tangan.

\section{a. Proses Penempatan Alat Cuci Tangan}

Kegiatan penempatan alat cucu tangan di musholat yakni sebagai tempat umum (warga beribadah) untuk menarik partisipati warga sekitar dalam menjaga kesehatan dengan mematuhi protocol kesehatan yang sudah di terapkan, sehingga dengan adanya cuci tangan ini warga akan terbiasa untuk menjaga kesehatan mulai dari hal yang kecil yakni cuci tangan dengan baik dan benar.

\section{b. Proses Pembutan Pamflet}

Dalam proses pembuatan pamflet yang dilakukan pertama kali adalah mendesain poster semenarik mungkin agar warga dapat terkesan degan peraturan yang sudah kita buat sehingga warga sekitar dapat meningkatkan kesadaran mereka terhadap pentingnya akan kesehatan salah satunya adalah peringatan mencuci tangan dengan baik dan benar. Famflet ini tidak hanya di tempelkan di msusholah akan tetapi juga di temple di tempat umum (rumah warga) yang menjadi pusat pembelajaran anakanak (tempat les).

Dalam pamflet ini berisikan 5 himbauan dalam cegah penyebaran virus corona (covid 19) yakni:

1) Selalu jaga kebersihan tangan (cuci tangan dengan benar)

2) Saat bersin, tutup hidung dan mulut dengan saputangan atau masker.

3) Jaga jarak dengan yang sakit. Hindari menyentuh mata, hidung atau mulut.

4) Kurangi bepergian jika merasa tidak enak badan.

5) Makan makanan yang bergizi dan istirahat yang cukup.

\section{c. Pemasangan Pamflet dan Penempatan Alat Cuci Tangan}

Pamflet dan penempatan alat cuci tangan yang telah di buat dan di siapkan tersebut kemudian dipasang di mushalah dan rumah warga. Dalam hal ini mengenai pemasangan pamflet dan penempatan alat cuci tangan berupaya untuk meningkatkan akan kesadaran dan membiasakan masyarakat mengenai pentingnya menjaga kesehatan diri dan lingkungan sekitar untuk mencegah akan adanya penularan covid-19. 


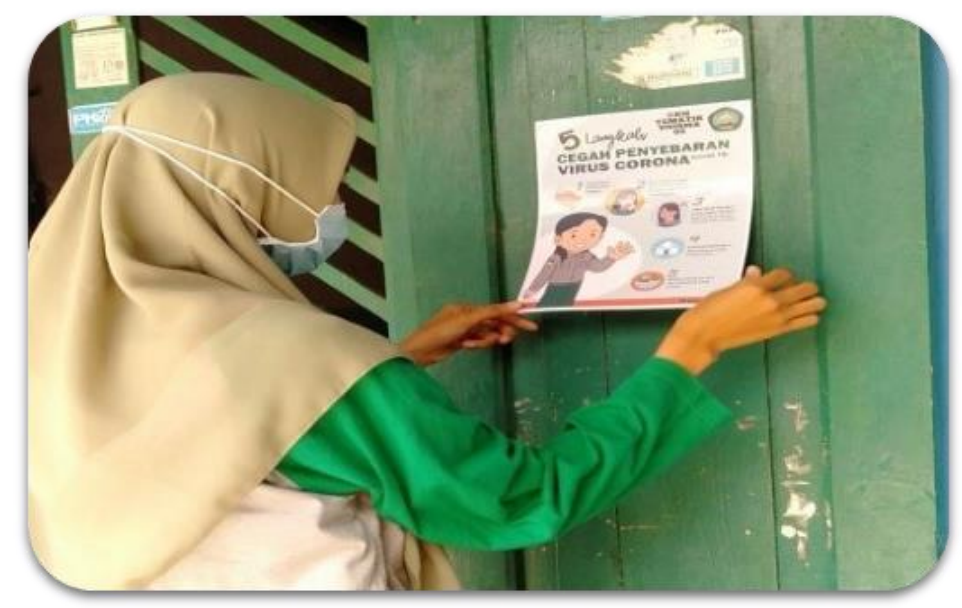

Gambar 2. Penempelan Pamflet di Rumah Warga (Sumber: Foto Pribadi)

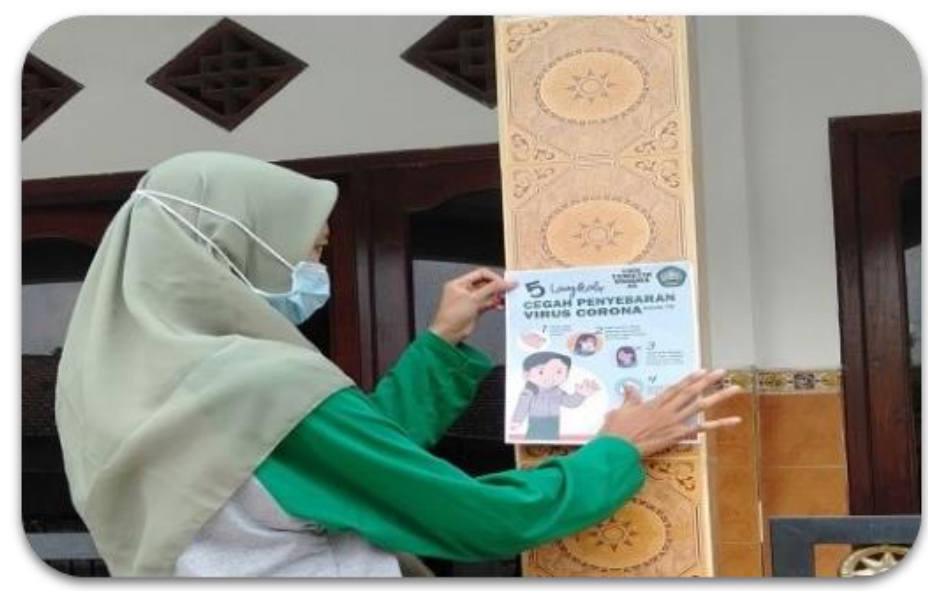

Gambar 3. Penempelan Pamflet di Masjid (Sumber: Foto Pribadi)

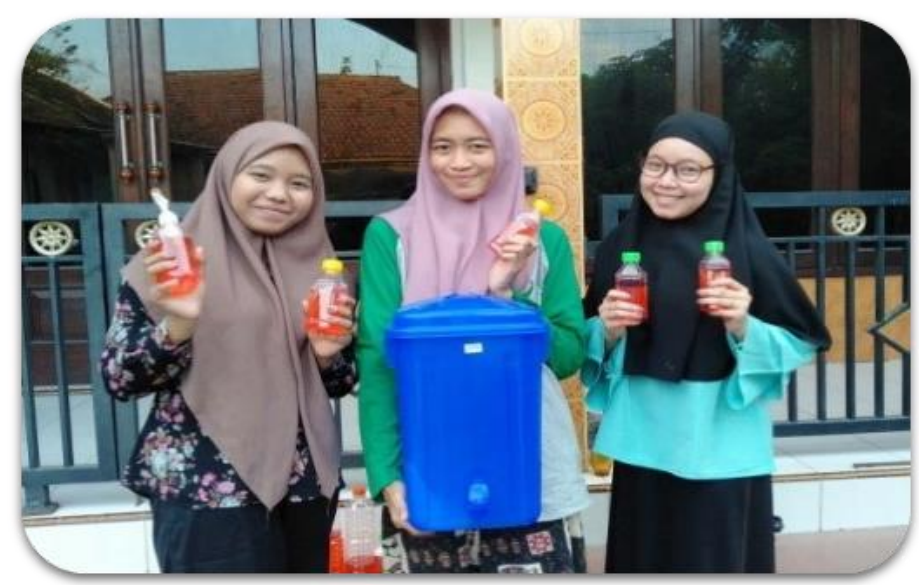

Gambar 4. Pemasangan tempat cuci tangan di mushola (Sumber: Foto Pribadi)

\section{Monitoring dan Evaluasi}

Monitoring dilakukan ketika program pengabdian sedang diimplementasikan. Monitoring diperlukan agar kesalahan awal dapat segera diketahui dan dapat dilakukan tindakan perbaikan, sehingga mengurangi risiko yang lebih besar. Tujuan dari monitoring ini adalah Manjaga agar program yang sedang diimplementasikan sesuai dengan tujuan dan sasaran. Menemukan kesalahan sedini mungkin sehingga 
mengurangi risiko yang lebih besar. Melakukan tindakan modifikasi terhadap kebijakan apabila hasil monitoring mengharuskan untuk itu.

Hasil monitoring menunjukan bahwa tahapan-tahapan yang dilakukan berjalan sesuai dengan tujuan dan sasaran. Pembuatan pamflet, penempelan pamflet dan penyediaan fasilitas mencuci tangan telah dilakukan dengan baik.

Evaluasi efektifitas kampanye melalui media pamflet dilakukan dengan membagikan angket kepada masyarakat sekitar, sehingga didapatkan data pemahaman warga terkait pencegahan Covid-19 serta cara cuci tangan yang baik dan benar yang kemudian data tersebut diolah sehingga didapatkan persentase keberhasilan program kerja yang dijalankan.

Dari 30 angket yang disebar kepada masyarakat sekitar lokasi KKN, 25 memberikan jawaban bahwa kampanye mencuci tangan melalui media pamflet dan penyediaan fasilitas mencuci tangan dapat meningkatkan kesadaran masyarakat terhadap pentinganya mencuci tangan, terutama di masa pandemi covid-19.

\section{KESIMPULAN}

Program kerja yang dilakukan mahasiswa KKN tematik kelompok 02 Di desa Kalijambon, Kec Tembelang, Jombang telah menunjukan hasil yang bagus terutama adanya tingkat kesadaran masyarakat terhadap pentingnya mencuci tangan di masa pandemi covid19. Selain itu kelompok 02 KKN Tematik UNISMA juga mendapat Dukungan serta respon yang sangat baik dari warga setempat karena program kerja yang dilakukan memiliki dampak yang Positif untuk warga serta meningkatkan kesadaran bagi warga untuk selalu menerapkan pola hidup yang sehat sesuai protokol kesehatan, kususnya dalam mencuci tangan setiap saat sebelum ataupun sesudah melakukan Aktifiitas.

\section{DAFTAR RUJUKAN}

Elgaputra, R. R., Sakti, E. Y. A., Widyandri, D. B., Azhari, A. R., Renatta, C., Rainasya, K., ... Musta'ina, S. (2020). Implementasi Sosialisasi Covid-19 Dalam Upaya Meningkatkan Kesadaran masyarakat terhadap Protokol Kesehatan di kota Jakarta. Jurnal Layanan Masyarakat, 4(2), 423-433. https://doi.org/10.20473/jlm.v4i2.2020.423-433

Janitra, F. E., Wijayanti, K., Wahyuningsih, I. S., \& Apriyanti, H. W. (2020). Peningkatan Kualitas Hidup Pasien kanker Payudara Melalui Program BESTCARE (Breast Cancer Wound and Palliative care). Jurnal Inovasi Hasil Pengabdian Masyarakat (JIPEMAS), 3(1), 46-53. https://doi.org/10.33474/jipemas.v3i1.4847

Mardiyani, S. A., Hidayatullah, M., Sofa, M. Z., Delphia, P., Muhamad, H., Nugraha, M. A. T., ... Syahputra, V. T. (2020). Edukasi Praktek Cuci Tangan Standar WHO dan Peduli Lingkungan. Jurnal Pembelajaran Pemberdayaan Masyarakat (JP2M), 1(2), 85-91. https://doi.org/10.33474/jp2m.v1i2.6531

Maria, G. A. R., \& Raharjo, S. T. (2020). Adaptasi Kelompok Usia Produktif Saat Pandemi Covid-19 Menggunakan Metode Reality Therapy. Jurnal Kolaborasi Resolusi Konflik, 2(2), 142-149. https://doi.org/10.24198/jkrk.v2i2.29124

Mona, N. (2020). Konsep Isolasi Dalam Jaringan Sosial Untuk Meminimalisasi Efek Contagious (Kasus Penyebaran Virus Corona Di Indonesia). Jurnal Sosial Humaniora Terapan, 2(2), 117-125. https://doi.org/10.7454/jsht.v2i2.86

Supriatna, E. (2020). Wabah Corona Virus Disease (Covid 19) Dalam Pandangan Islam. SALAM: Jurnal Sosial Dan Budaya Syar-I, 7(6), 555-564. https://doi.org/10.15408/sjsbs.v7i6.15247

Yamali, F. R., \& Putri, R. N. (2020). Dampak Pandemi Covid-19 Terhadap Ekonomi Indonesia. Ekonomis: Journal of Economics and Business, 4(2), 384-388. 
https://doi.org/10.33087/ekonomis.v4i2.179

Yatimah, D., Kustandi, C., Maulidina, A., Irnawan, F., \& Andinnari, S. R. (2020). Peningkatan Kesadaran Masyarakat tentang Pencegahan COVID-19 berbasis Keluarga dengan Memanfaatkan Motion Grafis di Jakarta Timur. Jurnal Karya Abdi, 4(1), 246-255. Retrieved from https://online-journal.unja.ac.id/JKAM/article/view/10530

Yunus, N. R., \& Rezki, A. (2020). Kebijakan Pemberlakuan Lockdown Sebagai Antisipasi Penyebaran Corona Virus Covid-19. SALAM: Jurnal Sosial Dan Budaya Syar-I, 7(3), 227-238. https://doi.org/10.15408/sjsbs.v7i3.15048 